\title{
VIA MEDIA AUREA
}

Nincs királyi út! Ha lenne, azt nem a könyvtárosoknak tartanák fenn. Nem is baj ez, hiszen a történelem éppen napjainkban bizonyítja, hogy a viszonylagos "királyi utat" bejárt nyugat-európai nemzedékek tagjai éppen azokat a képességeiket veszítették el, amelyek az „amikor nem adatik” korszakok túléléséhez szükségesek. Ez nem jelenti azt, hogy olyan jó, "ha nem adatik”, vagy azt, hogy akinek sohasem adatott, az minden olyan készséggel és tudással felvértezett, ami ahhoz kell, hogy élni tudjon a lehetőségekkel, „amikor adatik”.

Éppen két éve jelent meg a kolozsvári Magyar Történeti Intézet évkönyveként a Hagyomány és újítás a 21. századi könyvtárban című kötet, ${ }^{1}$ amelynek szerzői az erdélyi könyvgyújtemények aktuális feladatait veszik számba. Az írások tanulságai bármelyik mai könyvtárra igazak, különösen azokra, amelyeknek magyar bibliotékaként a mai Magyarország államhatárain kívül kell dolgozniuk. Nem csupán abban a kettősségben, amelyben minden mostani könyvtár dolgozik a világban. A feladatok egyik része hagyományőrzés. Vagyis egy közösség írott kulturális és tudományos örökségének a megőrzése, nyilvántartása és hozzáférhetővé tétele. Ezzel - és ez a fontosabb része a felelősségnek - nem egyszerűen örökséget őriznek és bocsátanak rendelkezésre. Alapjaiban járulnak hozzá ahhoz, hogy a nyelvi és kulturális közösség tagjai elvileg megőrizhessék innovatív, alkotó képességüket, ami anyanyelvi kompetencia - nyelvi, kulturális és tudományos hagyomány - nélkül nincsen.

Tudni kellene, mi is ez a „nyelvi, kulturális és tudományos hagyomány”. Ennek a tudásnak az alapja a tételes számbavétel és nyilvántartás. Ezzel kezdődik ugyanis az, hogy aztán különféle, egyre attraktívabb technikával ezt közzétesszük, rendelkezésre bocsátjuk. Ha nincsen mit felmutatni - és a könyvtárakban őrzött írott örökség túlnyomó része nem ismert a digitális világ számára még metaadat szinten sem -, akkor a közösség alkotó ereje is kiszolgáltatott. Különösen az olyan szirénhangoknak, amelyek a nemzetközi digitális tér "teljességéről”, „nyitottságáról” vagy éppen „demokratizmusáról” énekelnek.

\footnotetext{
1 RÜSZ-FOGARASI Enikő (főszerk.): Hagyomány és újítás, a 21. századi könyvtárban. Kolozsvár, Egyetemi Műhely Kiadó, 2018. A szám
} mentora Monok István. 
Egy további komoly veszély, ami az alkotóképességet veszélyezteti, az a bezárkózás a saját világunkba. Mi tudjuk legjobban, kik vagyunk; a kultúránkra és tudományunkra mindig lehet alapozni. Ahhoz, hogy tudjuk, kik vagyunk, meg kell ismernünk másokat; főként egy olyan úton, hogy megismerjük, mit gondolnak rólunk, és azt miért gondolják. Aztán meg kell ismernünk, hogy mások mit gondolnak a világról, a létezéstől kezdve a gyakorlati teendőkig. Ha csak előbbit ismerjük, nem tudunk cselekedni; ha meg csak az utóbbi - éljen az alkalmazható tudás -, elveszítjük alapjainkat, és másként válunk kiszolgáltatottá. Elemi dolog tehát - ahogy a magyar művelődés és tudomány történetében mindig -, hogy megismerjük mások tudását. Hozzá kell tehát férnünk mások örökségéhez és mások tudásához. Ehhez óriási lehetőség a digitális világ. Olyan lehetőség persze, mint ami mindig volt. Ha egy erdélyi vagy magyar királyságbéli ifjú tanulni, kutatni akart a kora újkorban, vagy akár a 20. században, el kellett jutnia valamelyik más országban múködő egyetemre. Sokba került az ilyen tanulmányi út. Ma sem olcsó, sőt. Miután a világ egy kis része monopolhelyzetben van lényeges ismeretek birtoklását tekintve (sajnos az ő kezükben koncentrálták a világ tudását), ma aránytalanul drágább az ilyen tudás megszerzése. Az már csak elkeserítő, hogy a több költséggel megszerzett tudás bezárultabb szakbarbárokat - kiszolgáltatott embereket - eredményez, hiszen még a világot sem láthatják tanulmányaik közben. Nem jelenti azonban ez, hogy nem kell az a ténylegesen alkalmazható, modern ismeret, illetve régi örökségi rész, amely csak ilyen úton és ezzel az áldozattal szerezhető meg.

Említettem, hogy a Magyarország határain kívül működő magyar könyvtárak nem egyszerü kettősségben - a hagyomány megismerésére, és a korszerű eszközök használatára kötelezetten - dolgoznak. Ma sokszor számukra sem, de legfőképpen az őket körülvevő többségi kulturális csoport tagjai számára sem egyértelmű - nem evidens, legfeljebb triviális -, hogy örökségük közös, és az ezzel kapcsolatos feladatok is azok. Így kulcsfontosságú, hogy a magyarországi magyar kulturális és tudománypolitikának részei maradjanak a határon túli magyar (és nem magyar) könyvtárak is. De hogyan segítsük őket? Sokféleképpen.

Számos esetben a centrum és periféria torz elképzelései mentén úgy próbáltuk segíteni munkájukat, ahogy a szegény rokonokhoz viszonyulunk. A politikai hatalomváltás időszakában, az 1990-es évek elején elárasztottuk könyvtáraikat magyar könyvekkel. Azokkal, amelyek nekünk már nem kellettek. Kiváló szép- és szakirodalommal, éppen csak még használható ismeretekkel, no meg nem kevés selejt anyaggal. A megjelölések viszonylagosságával tisztában vagyok. De elkezdődött az a folyamat is, ami a tényleges együttmúködés, ismeretek cseréjének az útja. Így jutottunk el a kihelyezett szemináriumok - modern eszközök használata könyvtárban -, a magyarországi felsőfokú képzésben való részvétel lehetőségének a biztosításán át addig, hogy a kulturális és tudománypolitika szerves részévé válhatnak. Szépen is hangzik ez, de sajnos nem létezik a szakmai körökkel egyetértésben megalkotott elképzelésrendszer. Az intézményeknek, ha valóban együttműködni akarnak, a mindig aktuális politikai - és sajnos nem szakmai - együttműködési 
lehetőségek mentén kell megtalálniuk és kihasználniuk a lehetőségeket. Ma sok ilyen lehetőség adatik.

Elmondhatjuk persze, hogy jobb lenne - könyvtárszakmailag mindenképpen -, ha a lehetőségek mindkét, nem szétválasztható munkaterületen is adódnának. De az is biztos, hogy a jövő könyvtárosának is alapvető fontosságú a via media aurea fenntartása. Lehet valaki modern, ha lövése sincsen arról a tartalomról, amit az információtechnológiai eszközökkel - ha valaki kifizeti - elér, és lehet valaki nagyon olvasott, múvelt, ha digitális analfabéta marad. A könyvtárosnak a jövőben a két analfabéta - a műveletlen klikkelgető és a digitális analfabéta - csoport közti közvetítés is feladata lehet.

Prof. Monok István

a Magyar Tudományos Akadémia Könyvtár és Információs Központ főigazgatója 